\title{
EL CANJE DE PRISIONEROS DE GUERRA DURANTE EL PERIODO DE INDEPENDENCIA Y SUS INCIDENCIAS EN LA COSTA CARIBE DE LA NUEVA GRANADA Y VENEZUELA
}

ROGER PITA PICO*

\section{RESUMEN}

Este trabajo analiza el canje de prisioneros de guerra en la Costa Caribe de la Nueva Granada y Venezuela tras la firma de los tratados de armisticio y de regularización de la guerra a finales de 1820. Se examina el alcance de esta medida humanitaria y particularmente su aplicación después de suspendida la tregua y en las capitulaciones suscritas en las plazas que aún estaban bajo dominio español. Pese a todas las dificultades, cientos de militares pudieron por esta vía salvar sus vidas mientras que otros regresaron a sus filas o al seno de sus familias. Se encuentra que mayores fueron las ventajas para el bando republicano pues un buen número de prisioneros españoles abandonaron los territorios en disputa y otros adhirieron a las filas patriotas mientras que el ejército expedicionario espanol fue paulatinamente perdiendo su poderío. En cierto modo, esta fórmula de intercambio de prisioneros ayudó a mantener los canales del diálogo y las salidas negociadas en esta última fase de las guerras de Independencia, y constituye un importante precedente del derecho internacional humanitario.

"El autor es Director de la Biblioteca "Eduardo Santos" de la Academia Colombiana de Historia. Correo electrónico: rogpitc@hotmail.com. Este artículo es el resultado parcial de una investigación más amplia titulada "Las rutas de la paz y la negociación durante el proceso de Independencia de la Gran Colombia, 1810-1825". Recibido: febrero 26 de 2019; aceptado: 20 de junio de 2019.

Economía \& Región, Vol. 13, №. 1, (Cartagena, junio 2019), pp. 145-176. 
Palabras clave: Colombia, Venezuela, Costa Caribe, prisioneros de guerra, paz, acuerdos, España, Independencia, siglo XIX.

Clasificaciones JEL: Z19, Y80, N96.

\begin{abstract}
The exchange of prisoners of war during the period of Independence and its incidence in the Caribbean Coast of New Granada and Venezuela

Within the framework of the bicentennial of the independence of the Hispanic-American nations, this essay exmines the exchange of prisoners of war in the Caribbean coast of New Granada and Venezuela after the signing of the armistice and regularization of war treaties at the end of 1820. I study the scope of this humantiarian accord, particularly after the suspensión of the truce, and in the capitulations in towns that were still under Spanish control. Despite many difficulties, hundreds of soldiers were able to save their lives this way, while many others returned to the ranks of the military or went back to their families. I find that the benefits were greater for the Republican side because a good number of Spanish prisoners abandoned the territories under dispute and others joined the revolutionary troops, while the Spanish Expeditionary Army was slowly losing its grip on the rebel colonies. In a way, the exchange of prisoners of war helped maintain channels of dialogue. It thus helped to produce a negotiated exit in this last phase of the wars of Independence and became an early precedent of international humanitarian law.
\end{abstract}

Key words: Colombia, Venezuela, Caribbean Coast, prisoners of war, peace, agreements, Spain, Independence, 19th century.

JEL Classifications: Z19, Y80, N96.

\title{
I. INTRODUCCIÓN
}

Los prisioneros de guerra eran combatientes capturados por el enemigo durante un conflicto armado o al término de este. Tomar prisioneros de guerra se 
consideraba parte de los derechos legítimos de defensa de cada una de las partes beligerantes pues se tenía como propósito desorganizar y menguar las fuerzas de ataque y resistencia del bando oponente. Históricamente, la práctica de tomar prisioneros de guerra se remonta a los tiempos de la Antigüedad, aunque las posibilidades de intercambio o canje empezaron a registrarse desde la Edad Media. En esta época la Iglesia logró que solo se hiciesen prisioneros a los combatientes, lo cual significó un avance fundamental con relación a lo que sucedía en la Antigüedad en donde solía extenderse la captura de prisioneros a la población civil. En los inicios de la era moderna aumentaron los esfuerzos por mejorar el trato de los prisioneros y se abogó por sus derechos individuales en el marco de los principios liberales propugnados por la Revolución Francesa (Martínez-Radío, 2013, p. 50). En América el tema de los prisioneros de guerra se constituyó en tema de discusión en la segunda mitad del siglo XVIII durante el proceso de Independencia de los Estados Unidos (Wheaton, 1861, p. 343).

En España se legisló tempranamente sobre los prisioneros de guerra, llegándose a incorporar en las ordenanzas militares ${ }^{1}$. Esta temática adquirió mayor relevancia en el marco de las revoluciones hispanoamericanas de principios del siglo XIX y la confrontación política y militar entre las fuerzas españolas y las huestes que luchaban por la independencia nacional. ${ }^{2}$

En particular, la Independencia de la Nueva Granada ha registrado cambios sustanciales en materia historiográfica pues los primeros estudios se dedicaron más que todo a exaltar héroes y batallas. Desde la segunda mitad del siglo XX, con la profesionalización de la historia como disciplina y la introducción de técnicas y métodos científicos, se amplió el abanico de temáticas en un intento por profundizar otras facetas, como la social, la económica y la cultural. Una nueva mirada en la que han adquirido relevancia otros espacios, otras dinámicas y otros actores antes invisibilizados como los sectores bajos de la sociedad (Reyes, 2012, pp. 57-58).

En el marco de estas guerras, fueron varios los destinos de los militares tomados como prisioneros: la cárcel, el trabajo forzado, el reclutamiento en las fuerzas captoras o, en los casos más extremos y radicales, el cadalso. Al no haber normas

\footnotetext{
${ }^{1}$ Las ordenanzas militares eran leyes o estatutos elaborados para el régimen de los militares y el buen gobierno de la tropa (Salas, 1992, pp. 17-25).

${ }^{2}$ Sobre la situación de los prisioneros de guerra en España véase García Hurtado (2011) y Fajardo (2014, pp. 175-236).
} 
acordadas entre los dos bandos en conflicto, lo que primó durante este período fue la represión e intolerancia hacia los prisioneros de guerra con muy pocas vías pacíficas de solución.

El proceso de Independencia en la Nueva Granada ${ }^{3}$ se inauguró en 1810 con la etapa conocida como la Primera República Federativa, tiempo durante el cual la Costa Caribe neogranadina fue escenario de una estrecha disputa regional entre la provincia de Cartagena, que desde un comienzo se declaró adepta al proyecto independentista, y la vecina provincia de Santa Marta, que se erigió como un bastión de la resistencia monárquica.

En Venezuela, el movimiento revolucionario comenzó también en 1810 y se consolidó al año siguiente con la declaratoria de independencia. Se desarrolló en este territorio una lucha prolongada y cruel entre realistas y patriotas con alternancia continua en el poder y con un fuerte componente de disensiones entre castas y grupos sociales. Hacia 1812 cae la Primera República tras la invasión del oficial español Domingo Monteverde quien con el apoyo de los pardos y sectores bajos de la población presionaron a Francisco Miranda a firmar el 25 de julio una capitulación. Tras la derrota, Simón Bolívar buscó el exilio y emprendió luego, con el apoyo de los neogranadinos, la Campaña Admirable, que culminó con la toma de Caracas el 6 de agosto de 1813 y la restauración de la Segunda República. Sin embargo, al año siguiente fue enviado el español José Tomás Boves para contrarrestar los avances de los patriotas y el 11 de diciembre de 1814, en la batalla de Maturín, logró liquidar la Segunda República.

Derrotados los militares franceses en la península ibérica, el Rey Fernando VII restituyó en 1814 el Absolutismo y se dio a la tarea de reintegrar su Imperio, para lo cual impartió orden de reconquistar por la vía militar las colonias americanas que habían declarado su independencia. Para cumplir ese derrotero, se envió desde la metrópoli un fuerte ejército liderado por el comandante Pablo Morillo, cuyo primer objetivo fue someter las plazas costeras de la Costa Caribe de Nueva Granada y Venezuela, lo cual le abrió el camino para la vertiginosa recuperación del resto del territorio y la restauración del sistema monárquico.

El 7 de abril la expedición de Morillo tocó tierra cerca de Carúpano. A los dos días arribó a la isla de Margarita, donde logró la rendición del último reducto patriota en Venezuela. Luego de pasar por La Guaira, Caracas y Puerto Cabello,

\footnotetext{
${ }^{3}$ La Nueva Granada corresponde en términos generales al territorio de lo que en tiempos de la Gran Colombia se denominó Departamento de Cundinamarca y a lo que hoy se conoce como República de Colombia.
} 
el 5 de julio partió Morillo hacia la costa neogranadina no sin antes dejar una respetable guarnición de defensa. El siguiente objetivo de Morillo era someter a la plaza de Cartagena, lo cual le abrió el camino para la vertiginosa recuperación del resto del territorio neogranadino (Lynch, 1983, p. 265).

Las fuerzas emancipadoras no desistieron de su proyecto político y militar. Hacia 1817 Bolívar dio inicio en Venezuela a una nueva campaña que condujo a la liberación de la provincia de Guayana. Desde allí organizó tropas e instaló el Congreso de Angostura, que le imprimió un respaldo institucional y liberal al proyecto independentista. En los dos años siguientes, Bolívar concentró sus esfuerzos en liberar la Nueva Granada, para lo cual organizó de manera conjunta con tropas neogranadinas y venezolanas una campaña que culmina exitosamente con la batalla de Boyacá el 7 de agosto de 1819, que despejó el camino para ocupar la ciudad de Bogotá.

Cuatro meses después de esta victoria militar, el Congreso de Angostura aprobó la Ley Fundamental de la República (1819, p. 1), que creó la Gran Colombia. De esta manera se legitimó oficialmente la unión de la Nueva Granada y Venezuela dentro de la lucha mancomunada de ambos pueblos por alcanzar la Independencia.

En cuanto a lo militar, durante este tiempo las tropas republicanas se dedicaron a organizar varias campañas cuyo propósito era retomar el dominio sobre todo el territorio de la Nueva Granada. En los primeros meses de 1820, tras haber podido dominar el área central y la franja nororiental, los esfuerzos militares se orientaron a liberar la cuenca baja del río Magdalena y la región Caribe para lo cual se designó como cabeza de estas operaciones al coronel Mariano Montilla. Los oficiales José María Córdova y Hermógenes Maza lograron tras varios choques militares controlar el río Magdalena. En junio el almirante Luis Brión logró desembarcar junto con la legión irlandesa en su intención por expulsar a los realistas de Riohacha. Entre tanto, el coronel Montilla reorganizó sus huestes y logró liberar a Santa Marta en el mes de noviembre (Sourdís, 1994, pp. 181-189).

Tras estos avances alcanzados por las huestes republicanas, las fuerzas realistas se habían concentrado en la plaza de Cartagena, que se erigió como el último bastión en este territorio costero de la Nueva Granada. Montilla mantenía cercada por tierra a la ciudad amurallada desde el $1^{\circ}$ de julio, mientras que el almirante José Prudencio Padilla hacía lo propio por vía marítima.

Paralelamente a estas acciones, el otro propósito del general Bolívar fue lanzar la ofensiva sobre Venezuela, para lo cual, desde finales de 1819 y durante todo el año de 1820, sus esfuerzos se dirigieron a conseguir recursos y aumentar las labores 
de reclutamiento principalmente en las áreas liberadas de la Nueva Granada, pie de fuerza que fue concentrándose en la zona fronteriza de los valles de Cúcuta y San Cristóbal.

Por esos días el ejército expedicionario español mostraba signos evidentes de debilitamiento a causa de las deserciones, enfermedades y falta de recursos, replegados en actitud defensiva en la región costera y en el occidente de Venezuela. Muy estratégica era la Costa Caribe, por cuanto posibilitaba la entrada de soldados, armamento y recursos desde el exterior, además de la posibilidad de establecer vínculos diplomáticos con otras naciones. No en vano la zona costera se constituyó en epicentro de conflictos en la fase final de la guerra independentista.

La tendencia conciliadora surgida a partir de 1820 en el mundo hispanoamericano no debe interpretarse exclusivamente como una manifestación espontánea surgida en el Nuevo Mundo. Es necesario ligarla al contexto externo y a los efectos de lo que ocurría en España. Bastante convulsionado había comenzado el año en la península. Después del levantamiento liberal de Riego, fueron convocadas las Cortes y se restableció la Constitución de Cádiz, a la cual el Rey Fernando VII elevó su juramento. Las Cortes dejaron sin piso el proyecto de enviar tropas de refuerzo desde España y manifestaron su intención de restaurar el dominio español en América a través de una amnistía general, para lo cual se mostraron dispuestas a hacer concesiones, prometiendo a las fuerzas insurgentes que conservarían el poder de las provincias que hubiesen conquistado, pero con la condición de que estas debían depender de España (ACH, F. Archivo La Torre, t. I, pp. 112-116).

Tras diversas vacilaciones y desencuentros (AL, Correspondencia Oficial, Sección 8 , doc. 5.870), el comandante en jefe español, Pablo Morillo, y el presidente Simón Bolívar decidieron nombrar sus respectivos delgados como encargados de la negociación y, finalmente, el 25 de noviembre en la ciudad de Trujillo fue firmado un tratado de armisticio (Gazeta Extraordinaria de Bogotá, diciembre 17 de 1820; BNC, F. Pineda, t. 852, pieza 20). En el encabezado del documento ambos gobiernos expresaron su voluntad de superar las discordias, para lo cual había que dar el paso crucial de suspender todas las operaciones terrestres y marítimas durante el lapso de seis meses contados desde el momento en que se comunicara la ratificación del convenio. No obstante, bajo el principio de la buena fe y de los deseos "sinceros" de terminar la guerra, el cese al fuego podía prorrogarse por el tiempo que fuese necesario mientras se desarrollaban las negociaciones.

Los integrantes de uno y otro ejército debían permanecer en las posiciones que ocupaban al momento de notificarles la suspensión de hostilidades, para lo 
cual era imperativo señalar límites "claros y bien conocidos". Para el caso del conflicto vivido en Venezuela se acordaron previamente los límites. Si se llegaba a romper el armisticio, no podían reabrirse las hostilidades sin el previo aviso al adversario cuarenta días antes de que se ejecutara el primer acto de hostilidad.

Con el fin de brindar un testimonio de los principios "filantrópicos" que inspiraron a ambos gobiernos para acabar con los excesos y horrores que habían caracterizado al conflicto, se firmó el 26 de noviembre un tratado de regularización conforme al derecho de gentes y a las prácticas más humanas de las naciones civilizadas, cuyo punto central fue el canje de prisioneros (AGn, F. Enrique Ortega Ricaurte, caja 121, carpeta 1, ff. 1r-8r). Ambos tratados fueron refrendados el 27 de noviembre en un histórico encuentro amistoso entre Bolívar y Morillo en la población de Santa Ana (Rodríguez, t. IV, pp. 320-330).

Teniendo en consideración estos antecedentes, este ensayo tiene por objeto analizar el canje de prisioneros de guerra en la Costa Caribe de la Nueva Granada y Venezuela tras la firma del tratado de armisticio y de regularización de la guerra. El trabajo examina el alcance de esta medida humanitaria y particularmente su aplicación después de suspendida la tregua y en las capitulaciones firmadas en las últimas plazas que estaban bajo dominio español. Pese a todas las dificultades, cientos de militares pudieron por esta vía salvar sus vidas mientras que otros regresaron a sus filas o al seno de sus familias. Se encuentra que mayores fueron las ventajas para el bando republicano pues un buen número de prisioneros españoles abandonaron estos territorios en disputa y otros se adhirieron a las filas patriotas mientras que el ejército expedicionario español fue paulatinamente perdiendo su poderío. En cierto modo, esta fórmula de intercambio de prisioneros ayudó a mantener los canales del diálogo y las salidas negociadas en esta última fase de las guerras de independencia, y constituye un importante precedente del derecho internacional humanitario.

Este trabajo se inscribe dentro del área de los estudios de la paz. El propósito es avanzar hacia una nueva mirada del periodo de independencia pues la historiografía se ha preocupado más que todo en una apología del heroísmo militar, al desarrollo de las batallas y a las estrategias militares aplicadas. Resulta pertinente también mirar el proceso de emancipación desde la perspectiva de la negociación y de la búsqueda de la paz (Alfaro, 2013, p. 54). Este tipo de análisis puede arrojar

${ }^{4}$ Sobre este tipo de temáticas, pueden consultarse otros trabajos, como por ejemplo Correa (2014, pp. 288-311), Rodríguez (2016, pp. 321-378) y Castaño (2012, pp. 323-368). 
algunas luces para entender de manera más integral la complejidad de esta convulsionada etapa de la historia binacional.

Para el desarrollo de la investigación fue clave la consulta de fuentes primarias de información, en especial con fondos documentales archivo tanto en España como en Colombia y Venezuela. A esto se suma la consulta del intercambio epistolar entre autoridades políticas y militares, los informes oficiales, las memorias, las crónicas, los diarios de campaña y los artículos de prensa de la época.

\section{LOS PRISIONEROS EN EL TRATADO DE REGULARIZACIÓN}

Ningún otro tema despertó tanto interés en el tratado de regularización suscrito el 26 de noviembre de 1820 como el de los prisioneros de guerra. Prueba de ello es que ocho de los 14 artículos de aquel convenio hacían alusión al problema.

El artículo 2 definió como prisioneros de guerra a todos aquellos militares o dependientes de un ejército tomados en el campo de batalla, incluso antes de decidirse el combate. Estos hombres debían ser tratados y respetados conforme a su grado militar hasta lograrse su canje. En el artículo 3 se estipuló que serían igualmente considerados prisioneros de guerra aquellos capturados en marchas, destacamentos, partidas, plazas, guarniciones y puestos fortificados, aun cuando fueren tomados mediante asalto en tierra o mediante abordaje, en el caso de la marina.

En los artículos 5 y 6 se estableció que el canje de prisioneros debía realizarse "clase por clase y grado por grado" o mediante la entrega por algún superior de un número preciso de subalternos, según lo que se acostumbraba en las naciones "cultas". Serían igualmente comprendidos en el canje y considerados como prisioneros de guerra aquellos militares o paisanos que, individualmente o en partidas, hicieren el servicio de reconocer u observar o tomar noticia de un ejército para suministrarla al jefe del otro bando. Dicho en otras palabras, los espías tendrían el mismo tratamiento que los prisioneros de guerra a fin de ser redimidos de la fuerza represora, norma que se constituiría en un precedente sin igual en el derecho internacional humanitario y que había sido sugerida el 23 de noviembre por los comisionados republicanos (Valencia, 1992, p. 31; Manifiestos, p. 33).

El canje de prisioneros sería de obligatorio cumplimiento y debía efectuarse a la mayor brevedad posible. Siempre debían permanecer los prisioneros dentro del territorio de Colombia sin importar su grado y dignidad, y bajo ningún motivo ni pretexto podían alejarse para sufrir castigos en otros lugares. 
Era responsabilidad de los jefes de los ejércitos velar porque los prisioneros fueran asistidos, debiendo cada gobierno abonar mutuamente los costos que su sostenimiento acarreara. Además, los jefes quedaban facultados para nombrar comisarios encargados de garantizar la mejor atención a los depósitos de prisioneros con el fin de hacer menos penosa su existencia. Finalmente, en el artículo 10 se convino que estas normas proteccionistas cobijarían también a los prisioneros existentes al momento de la firma del tratado (AGN, F. Enrique Ortega Ricaurte, caja 121 , carpeta $1, \mathrm{ff} .1 \mathrm{r}-8 \mathrm{r})$.

\section{EL CANJE DE PRISIONEROS EN LA COSTA CARIBE NEOGRANADINA EN TIEMPOS DEL ARMISTICIO}

En el territorio neogranadino existieron algunos antecedentes que daban cuenta del destino incierto y casi siempre fatídico que les deparaba a los prisioneros de guerra. Como señal contundente de escarmiento, el 24 de febrero de 1816 el comandante en jefe español, Pablo Morillo, ordenó dentro de su ofensiva de Reconquista en la plaza de Cartagena, el fusilamiento de nueve prisioneros de guerra que eran las cabezas visibles del régimen republicano en esa ciudad (Sourdís, 2011, pp. 297-335).

Otro hecho que causó gran conmoción y controversia en la Nueva Granada sucedió el 11 de octubre de 1819, cuando el vicepresidente Francisco de Paula Santander ordenó el fusilamiento de 39 militares españoles capturados en la batalla de Boyacá (Salazar, 1990, p. 87).

Santander justificó su decisión con el argumento de que se había tratado con generosidad a estos prisioneros tan pronto llegaron a la ciudad de Bogotá. Enseguida se comenzaron a difundir mensajes "subversivos" con los que se pretendía no solo desalentar el ánimo de los patriotas sino ganar adeptos a la causa del Rey. Según las informaciones recibidas, aquellos oficiales se habían dedicado también a ofrecer protección a los oficiales republicanos que les hacían la guardia y habían intentado persuadir a algunos de los soldados que antes pertenecían al ejército realista y que ahora estaban enrolados en el ejército Libertador. Incluso se dijo que uno de esos oficiales había intentado vestirse de mujer para fraguar su huida. Recordaba, además, el general republicano las crueldades cometidas por algunos oficiales españoles contra militares patriotas, como por ejemplo la decisión de degollar a varios soldados prisioneros en el combate de Gámeza. 
De otra parte, Santander consideraba que el virrey Sámano no podía efectuar el canje propuesto por Bolívar pues todos los jefes españoles habían declarado cortar cualquier tipo de comunicación con los "insurgentes" y porque se había sabido que aquel había impartido orden expresa al gobernador de Panamá de fusilar a todos los extranjeros prisioneros en Portobelo. Otro motivo que no hacía viable aquella propuesta conciliadora era que, en el momento, no había ningún oficial republicano en manos de los españoles y porque, además, los patriotas detenidos en Cartagena, plaza que en esos momentos estaban bajo el poder de los españoles, gozaban de libertad absoluta por cuenta de haber sido incluidos en un indulto decretado en 1817.

Este cúmulo de circunstancias fueron para Santander más que suficientes para inclinarse por la sentencia aplicada a Barreiro y a los demás oficiales españoles, pues no veía condiciones para defender a esta provincia recién liberada manteniendo allí a dichos prisioneros. La ciudad estaba alarmada y temerosa con su presencia. Por lo menos aseguró sentir tranquilidad en su conciencia al haber recibido voces populares de apoyo a la medida (Lecuna, 1942, t. I, p. 85).

En el cruel ataque realizado por las fuerzas del gobernador de la plaza de Cartagena contra el cuartel general de los republicanos en Turbaco, a principios de septiembre de 1820 (Dousdebés, 1948, 237-239), los realistas capturaron a varios prisioneros que fueron llevados a Cuba (Gaceta de Caracas, octubre 25 de 1820, p. 72).

Luego de que las tropas republicanas se habían apoderado de Santa Marta, el 9 de diciembre de 1820 el vicepresidente Santander envió al comandante general del ejército una nota en la cual le planteaba que, en el marco de la regularización de la guerra, era necesario conservar los oficiales y soldados prisioneros en los combates que habían precedido la ocupación de la plaza, suministrándoles los auxilios para su subsistencia. Los oficiales prisioneros que habían pertenecido al bando republicano y desertaron de las manos de los españoles debían ser juzgados por un consejo de guerra. Aunque en tiempos del armisticio era de creerse que este juicio se suspendiera, se pensaba también que el tratado de regularización no se extendía a los traidores en tiempos anteriores (Archivo Santander, t. v, p. 335).

Habiéndose ya conocido la firma del tratado de regularización de la guerra, el coronel Mariano Montilla, comandante en jefe del ejército republicano que operaba en la Costa Caribe neogranadina, prometió el 17 de diciembre, en aras del derecho de gentes, proteger al prisionero subteniente Antonio Fominaya, siempre y cuando no estuviese en peligro la seguridad pública. Este criollo había sido 
perdonado por el general Simón Bolívar a su ingreso a Bogotá a los pocos días de la batalla de Boyacá y luego fue destinado a servir en los ejércitos que operaban en Venezuela, de donde se fugó para volver a las filas realistas. Montilla pidió que Fominaya fuera tratado como un reo (AGN, F. Enrique Ortega Ricaurte, caja 80, carpeta 17, f. 38r).

Al llegar a Santa Marta para iniciar las negociaciones en torno a la demarcación de territorios en el marco del armisticio acordado, el comisionado español Manuel Landa recibió en calidad de canje a un sargento $1^{\circ}$ y a un cabo $1^{\circ}$. A cambio, Montilla reclamó el 9 de enero la entrega de los militares Juan Anzoátegui y Damián González. El primero de ellos había caído preso en la isla de Margarita y fue obligado a servir como sargento $2^{\circ}$, mientras que González fue capturado por los españoles a su entrada a la plaza de Cartagena. Al día siguiente, Landa no remitió los dos individuos solicitados pero a cambio de ellos envió a Francisco Lara e Ignacio Vargas. Se aclaró que Anzoátegui y González solo podían canjearse por otros de su misma graduación (AGn, Fondo Secretaría de Guerra y Marina, t. 333, f. 137r; León, 1985, Vol. I, p. 68).

Tras el incidente de la invasión del capitán de milicias españolas José Candamo a los pueblos neutrales de Sabanas ubicados al suroeste de Cartagena, el coronel Montilla pensó que había que tomar retaliaciones por esos excesos. Por esta razón anunció al gobernador español de la plaza, don Gabriel de Torres, la decisión de poner en estrecha reclusión a los prisioneros realistas que hasta ese momento habían gozado de "completa libertad y consideración". Se había visto obligado a adoptar tal medida al enterarse de que, aún después de publicados los tratados, había prisioneros republicanos que llevaban hierros atados a los pies o que eran empleados en "duras y viles" ocupaciones. Según Montilla, ninguna conducta se le podía reprochar en relación con el trato a los prisioneros, tal como lo podían corroborar el comisionado Landa y algunos españoles liberados que en ese momento se paseaban libremente por las calles de Cartagena (Briceño, 1971, p. 107).

Por su parte, el gobernador Torres elaboró al día siguiente una lista de 20 detenidos republicanos entre los cuales había algunos remitidos tiempo atrás por el virrey Juan Sámano y por algunos jueces. De igual modo, Montilla preparó una relación de los prisioneros españoles que se hallaban en los territorios ocupados por el ejército patriota: cinco originarios del cuerpo nacional de Artillería, ocho del regimiento de Infantería de León, uno del $2^{\circ}$ batallón del Regimiento del Rey, uno del Batallón Voluntarios de Valencia, uno del batallón Voluntarios de Aragón, otro de la Compañía de Voluntarios y tres soldados de Caballería (AGN, Fondo Secretaría de Guerra y Marina, t. 333, f. 138r). 
Montilla anunció además que había librado las órdenes a toda la provincia para que suministraran los datos precisos con los cuales cotejar las listas con miras a efectuar el canje. Al cabo de una semana, se depuró esta información haciendo la aclaración de que algunos por sus enfermedades se habían visto en el momento imposibilitados de emprender el viaje hasta el cuartel general de Turbaco.

Montilla aclaró que su gobierno solo consideraría prisioneros de guerra a aquellos que hubiesen servido a la República o alzado su voz en contra del régimen español, más no a los condenados por crímenes ajenos al servicio de las armas. Y sobre este punto le exigió al gobernador de la plaza obrar con absoluta sinceridad y rectitud. En respuesta a esta advertencia, Torres realizó una depuración de la lista inicial que quedó reducida a 14 individuos cuyos procesos fueron examinados "escrupulosamente". Esperaba el gobernador que la diferencia en relación con el grado exacto de los militares no fuera a perturbar la concreción del acuerdo de canje pues reconoció el error de haber confundido a un oficial registrándolo como sargento $2^{\circ}$. Para mayores detalles, los españoles especificaron la fecha en que aquellos hombres habían sido capturados.

La nueva lista incluyó a los siguientes militares republicanos: capitán de artillería Juan Salarria, aprehendido en 1815 en el Atrato, teniente Agustín Anzoátegui, subteniente Juan Anzoátegui, sargento 1 Juan Antonio Núñez, Nepomuceno Vicente Pífano, soldado Francisco Vertel, Carlos Carrillo, Pedro Torres, capturado en Zipaquirá el 4 de mayo de 1816, Juan José Lara, capturado en Nutrias en julio de 1816, Francisco Marchena, Jesús Silva, Manuel Martínez y Basilio Barrios.

Justo por estos días, el vicepresidente Santander impartió instrucciones precisas para agilizar este proceso de canje. En respuesta a ello, y como muestra de generosidad, el coronel Montilla, de común acuerdo con el gobernador Torres, prometió intercambiar a otros tres prisioneros españoles que tenía en su cuartel general de Turbaco: el mencionado subteniente Antonio Fominaya y los presbíteros Luis Villabrille y José Pío Plá. Montilla reconoció haber accedido a estas entregas no tanto motivado por sus propias convicciones sino estrictamente en acatamiento de las órdenes superiores (AGN, Fondo Secretaría de Guerra y Marina, t. 333, f. $136 \mathrm{r})^{5}$.

A las nueve de la noche del 21 de enero se dio orden para que abandonaran la plaza los 14 prisioneros patriotas definidos días antes y quedaron pendientes los

\footnotetext{
${ }^{5}$ Este canje de prisioneros fue destacado en las páginas de la prensa republicana (Gazeta de la ciudad de Bogotá, marzo 12 de 1821, p. 269).
} 
enfermos que fueran llegando al cuartel general. En respuesta a ello, esa misma noche los españoles recibieron en Torrecillas, en igual número, los prisioneros de las tropas del Rey que se hallaban cautivos en el cuartel general de Turbaco: el capitán graduado Pablo García, el ayudante Manuel Durán, el teniente don Gaspar Boygas, el sargento 1० Joaquín Urbina, el ayudante 2॰ Manuel Sandino Campo, el cabo $1^{\circ}$ Eusebio Arana, el ayudante Cándido Campo, el ayudante 2。 Juan Rodríguez, el tambor Francisco Concha, el ayudante Tiburcio Montilla y los soldados Manuel Valle, Eugenio Triguero, Ignacio Alcázar y Silvestre Hurtado.

Muy pronto se percataron en la plaza de Cartagena de que no habían sido entregados el subteniente español Fominaya ni los dos presbíteros. Más grave aún era la preocupación al saberse por voz de los prisioneros liberados que el joven Fominaya había quedado en una estrecha cárcel con grillos en espera de ser fusilado por haber tomado partido con las tropas realistas a las que antes había pertenecido luego de estar al servicio de la República. Según Torres, esta conducta iba en flagrante contravía del artículo $7^{\circ}$ del tratado de regularización de la guerra y además de todo ponía en cuestión el honor del ejército republicano. Así, entonces, bajo el amparo del acuerdo de canje, Torres elevó su voz de protesta para reclamar este oficial como "protegido bajo la salvaguardia del trato y de la humanidad".

El gobernador español exigió a Montilla reconsiderar de manera especial este punto, así como también la suerte de los presbíteros Plá y Villabrille. Le recordó que tuviera en cuenta el acto de generosidad que habían tenido los españoles al devolver algunos militares que, a pesar de ser acusados por los delitos de sedición, seducción y espionaje, de todos modos habían sido catalogados como prisioneros de guerra objeto de canje. En aras de la reciprocidad, el gobernador español apeló a la "buena fe y humanos sentimientos" de su adversario para que aprobara la inmediata liberación de Fominaya, hecho que se consideraba más que justo por tratarse de un menor de edad que debía ser amparado por las leyes.

La comandancia republicana aclaró que el trato riguroso dado a Fominaya era una forma de sancionar su conducta pero en ningún momento se previó aplicarle la pena capital pues, según la legislación vigente, este tipo de sentencia debía estar precedida de un consejo de guerra y del testimonio del reo. Aunque el vicepresidente Santander había impartido instrucciones el 11 de enero para brindar el mejor trato a los prisioneros dentro del marco de regularización, creía Montilla que esto no se aplicaba a Fominaya, a quien sentía que debía sentenciar a pena capital conforme a las Ordenanzas por ser traidor de la Patria. Sin embargo, decidió suspender cualquier decisión extrema mientras elevaba consultas a sus superiores, 
aunque era consciente que, de todas maneras, aquel reo debía recibir un justo castigo. Por lo pronto, se comprometió a retirarle los grillos y a brindarle un "trato humano".

Sobre los dos presbíteros, los republicanos denunciaron el hecho de que habían abandonado sus servicios espirituales para alistarse como soldados del Rey, intentando además persuadir al pueblo en contra de la causa independiente. A pesar de tal antecedente, se reiteró la firme voluntad de canjear a estos "sacerdotes marciales aprehendidos como guerrilleros", dejando a consideración del gobernador Torres la equivalencia de los grados con los que debían conmutarse (AGN, Fondo Secretaría de Guerra y Marina, t. 333, f. 141v).

El 10 de marzo, el presidente Simón Bolívar comunicó al general en jefe del Ejército Expedicionario español, don Miguel de La Torre, quien había reemplazado en este cargo a Morillo, la decisión de romper anticipadamente el tratado de armisticio en vista de las remotas esperanzas de entablar negociaciones de paz (RAE, signatura 9/5662, legajo 19c, f. 665r). Bolívar confirmó el rompimiento pero instó a de La Torre a cumplir con el tratado de regularización en materia de canje de prisioneros, pues el gobierno republicano había remitido los que tenían presos en Santa Marta y la isla de Margarita y, en tal sentido, esperaba una respuesta recíproca del bando adversario (AGN, Fondo Secretaría de Guerra y Marina, t. 329, f. 509r; (Blanco, 1875, Vol. vII, pp. 563-564).

Las conversaciones sobre el canje se reanudaron el 4 de abril cuando Montilla aclaró que no había en la plaza de Cartagena prisioneros republicanos de igual clase a los reclamados, razón por la cual se conformaba con los equivalentes que razonablemente le propusiesen. Torres exigió el pronto cumplimiento del canje, para lo cual había que finiquitar la entrega de don Antonio González, del calafate Isidro, del bergantín Andalucía, y del subteniente Fominaya. ${ }^{6}$ Para ello, propuso liberar un subteniente por otro, dos soldados por un teniente y otro soldado por el calafate. Si Montilla se negaba a aceptar esta "razonable" propuesta, para el gobernador español quedaba absolutamente clara la falta de palabra de los republicanos y la "infracción manifiesta" del tratado de regularización, pues se había llegado a publicar en la Gaceta de Bogotá el feliz cumplimiento de estas liberaciones.

El armisticio fue suspendido en estas provincias de la Costa Caribe neogranadina el $1^{\circ}$ de mayo, sin que se produjera esta última propuesta de intercambio

\footnotetext{
${ }^{6}$ El calafate era el encargado de cerrar las junturas de madera de una embarcación.
} 
tras la negativa de Montilla ante la creciente actitud hostil de los españoles. Finalmente, en los últimos días de junio, tras la toma de la bahía de Cartagena por las huestes patriotas, el vicepresidente Santander pidió verificar el canje bajo el entendido de que no se podía dar el más leve motivo para que se les culpara de mala fe o de evadir promesas (AGN, Fondo Secretaría de Guerra y Marina, t. 333, ff. 458r-544v). No habiendo prisión cómoda en donde alojar a los presbíteros Plá y Villabrille y, siendo perjudiciales estos hombres para la tranquilidad pública, ${ }^{7}$ el alto mando republicano dispuso que fueran enviados y liberados en la isla de Providencia. Les acompañaban en la deportación otros dos presbiteros: Manuel José Sáyago y Martín Diego Zapata (AGN, Fondo Secretaría de Guerra y Marina, t. 333, f. 606r-607r).

\section{LOS PRISIONEROS EN LAS CAPITULACIONES DE BOCACHICA Y CARTAGENA}

De alguna manera, el armisticio firmado en Trujillo había sentado un precedente en materia de humanización del conflicto. Las capitulaciones firmadas en los meses posteriores en Cartagena fueron precisamente un resultado de la voluntad de los republicanos y de los españoles de explorar vías negociadas que evitaran una mayor efusión de sangre en medio de una prolongada y cruenta lucha militar. Todo esto a pesar de que en el tratado de regularización nada se estipuló respecto a la opción del canje durante procesos de rendición y firma de capitulaciones (Mapa 1).

Terminada la fase de tregua estipulada en el pacto de Trujillo, el asedio republicano sobre la plaza de Cartagena se intensificó de manera notoria, siendo realmente crítica la situación para las sitiadas huestes españolas. El 4 de julio las fortalezas de Bocachica, ubicadas al sur de la plaza, cedieron ante la presión ejercida por las fuerzas sutiles republicanas al mando del coronel José Prudencio Padilla y se llegó a un acuerdo de capitulación. Esta vía pacífica se dio en razón a que la misma tropa y los oficiales españoles allí apostados habían obligado al teniente coronel

\footnotetext{
${ }^{7}$ Este sacerdote había caído prisionero en el combate de Fundación ocurrido en octubre de 1820 y, según comentó el coronel Mariano Montilla, había causado más males que le propio comandante Pablo Morillo y, por eso, llegó incluso a sugerirle al secretario de Guerra que fuera pasado por las armas (Archivo Histórico Restrepo, Fondo I, Vol. 15, pieza 5, f. 164r).
} 


\section{MAPA 1}

Flujo de los prisioneros de guerra de la Costa Caribe neogranadina y venezolana durante el periodo de Independencia

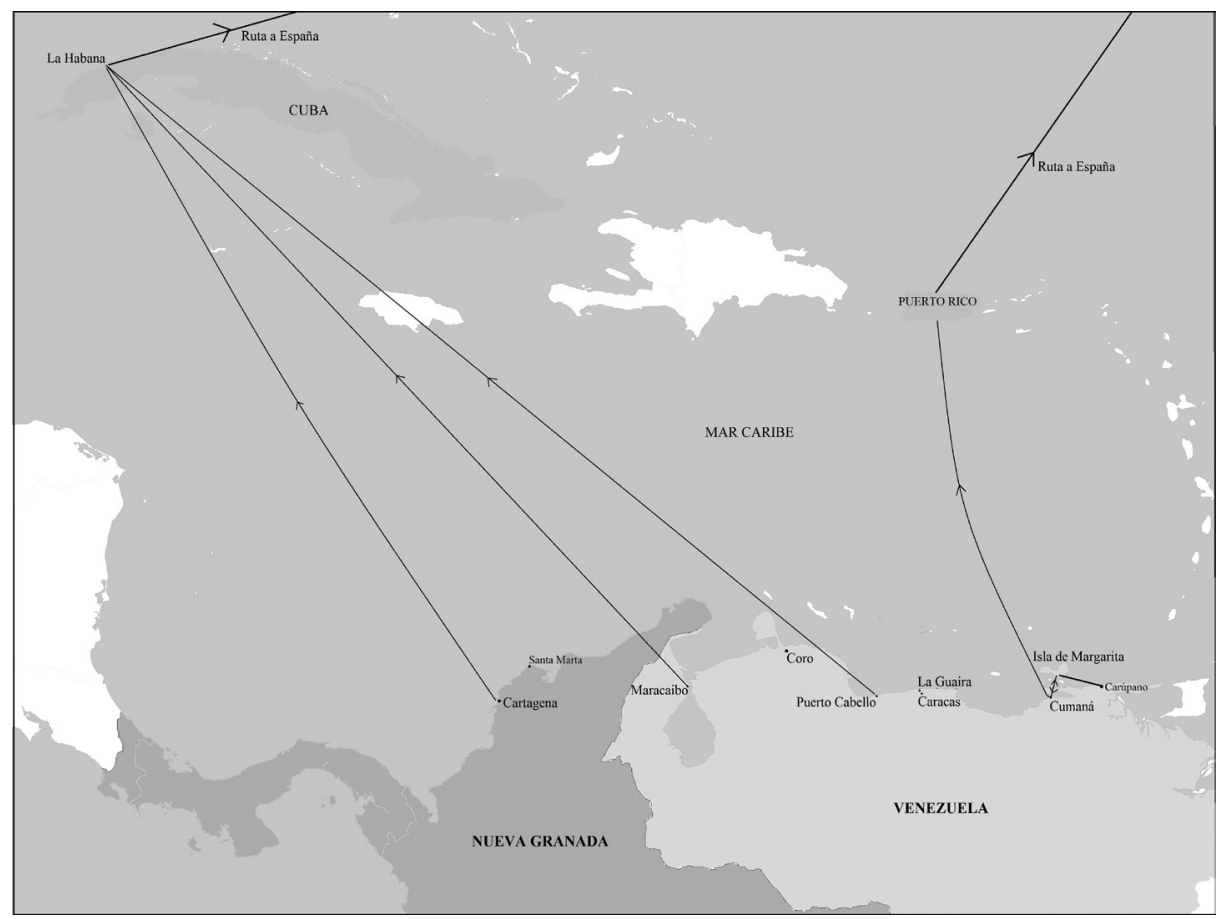

Fuente: Elaboración propia.

José María del Olmo, comandante de las fortalezas, a rendirse teniendo incluso algunos víveres para subsistir unos cuantos días más.

Del total de 174 militares españoles capturados, a algunos se les permitió integrarse a las armas republicanas, mientras que 23 fueron embarcados en el puerto de Santa Marta el 25 de julio (Ver Cuadro 1) en calidad de prisioneros de guerra con destino a La Habana (Cortázar, 1956, Vol. III, pp. 307-308).

Antes de zarpar del puerto, estos militares prestaron el siguiente juramento:

Juramos a Dios y prometemos a la nación española de quien dependemos que como prisioneros de guerra que hemos sido en los castillos de Bocachica de la plaza de Cartagena por las fuerzas de la República de Colombia de no tomar las 


\section{CUADRO 1}

Militares españoles embarcados el 25 de julio de 1821 a La Habana tras la capitulación de las fortalezas de Bocachica

\begin{tabular}{|l|l|}
\hline \multicolumn{1}{|c|}{ Grados } & \multicolumn{1}{c|}{ Nombres } \\
\hline Teniente coronel & José María del Olmo \\
\hline Capitanes & $\begin{array}{l}\text { Francisco Tamarís del batallón del Rey, Manuel del Basto del batallón de } \\
\text { Voluntarios de Valencia, Simón Álvarez del batallón de Voluntarios } \\
\text { de Valencia, Gerónimo Martorrell de las milicias del Chocó }\end{array}$ \\
\hline Subtenientes & $\begin{array}{l}\text { Blas Fernández, Francisco Domínguez, Manuel Cortés, Salvador de la } \\
\text { Rus, Pedro de Aguiar }\end{array}$ \\
\hline Sargentos 10 & Alonso Baquero \\
\hline Cabos 1० & Bernardo Manotas \\
\hline Cabos 2o & Francisco Linares \\
\hline Soldados & $\begin{array}{l}\text { Francisco Soriano, José González, José Cervantes, Antonio Sanz, José } \\
\text { Suñir, Pedro Hernández, Juan Rodríguez, José García, Felipe Rodríguez, } \\
\text { José Garea, Miguel Vecinas }\end{array}$ \\
\hline
\end{tabular}

Fuente: (AGN, Fondo Secretaría de Guerra y Marina, t. 333, f. 640r); (Gazeta de Santa Marta, agosto 18 de 1821, p. 59).

armas ni cometer ninguna hostilidad contra la República antes de ser canjeados según el derecho en la guerra y uso de las naciones civilizadas y para su validación firmamos este juramento en Santa Marta a 24 de julio de 1821 (AGN, Fondo Secretaría de Guerra y Marina, t. 333, f. 650r); (Gaceta de la ciudad de Bogotá, agosto 5 de 1821, p. 345).

Estos hombres fueron remitidos en la goleta holandesa Ana Catalina, a cuyo capitán, Santiago La Roche, se le pagaron 600 pesos por el flete, además de lo cual se pusieron a bordo los víveres indispensables para los 12 días de viaje.

A través de una nota firmada el día siguiente, el comandante republicano, José María Carreño, previno al capitán general de la Isla de Cuba sobre el envío de estos prisioneros de guerra, solicitándole toda la cooperación posible en aras del cumplimiento del juramento elevado por ellos, haciéndole énfasis en que a estos hombres se les había tratado con "generosidad".

El general La Torre, comandante en jefe del Ejército Expedicionario, pronto se enteró de estos acontecimientos y envió el 6 de julio desde su cuartel general 
una nota de agradecimiento al general Bolívar por sus "rasgos de humanidad" y "virtudes sociales", tras el buen trato brindado a estos prisioneros enviados a Cuba, mensaje que fue publicado en la prensa regional (Gazeta de Santa Marta, septiembre 8 de 1821, p. 70).

Hacia el mes de octubre de este mismo año, tras la intensificación del asedio de los republicanos y las penurias vividas al interior de la plaza de Cartagena, se formalizó la rendición definitiva de los españoles, con lo cual quedó liberada toda la Costa Caribe neogranadina, aunque persistieron algunas pequeñas escaramuzas en las áreas circundantes (Thibaud, 2003, pp. 454-455; Pita, 2017, pp. 57-89). A diferencia de lo estipulado en la entrega de las fortificaciones de Bocachica, en estas capitulaciones se definió que el gobernador, los oficiales y la tropa de la guarnición española no podían ser considerados como prisioneros de guerra.

Aunque el gobernador español, don Gabriel de Torres, propuso la liberación de todos los prisioneros capturados por los republicanos durante el sitio, al final se convino que no había lugar a esta solicitud porque ya habían sido canjeados o licenciados.

Otra de las propuestas del gobernador Torres era que los militares españoles y americanos que, por sus vínculos con esta provincia, quisieran quedarse voluntariamente en el servicio republicano, podían ser aceptados pero en calidad de canje por igual número de españoles prisioneros de igual rango y también podían ser permutados por algunos españoles o europeos que estuviesen al servicio de la causa independentista interesados en retornar a su país para lo cual debían salir junto con la guarnición. Sobre este punto, las partes convinieron en introducir una pequeña modificación en relación con la admisión de aquellos con voluntad de radicarse en estos territorios americanos pero no bajo la fórmula del canje por no haber en el momento prisioneros españoles en el ejército republicano que operaba en esta zona costera.

En su proclama lanzada desde Cospique el 24 de septiembre, el almirante republicano José Prudencio Padilla instó a su tropa y fuerzas sutiles a tener muy presente el tratado de regularización de la guerra, especialmente en lo atinente a los prisioneros: "Era cuestión de honor no quebrantarlo y observarlo rígidamente, pues así lo había encargado el Libertador Presidente y el comandante general de marina, bajo las más severas penas. Que no se diga otra cosa que su buen orden y subordinación para no desmerecer lo que tiene adquirido con su valor y constancia" (Corrales, 1883, t. II, pp. 472-473).

En la sesión del Consejo de Gobierno del 23 de abril de 1824 en Bogotá se recordó que en la plaza de Cartagena permanecía más de un centenar de oficiales 
españoles. Las alertas estaban encendidas por el reciente suceso ocurrido en El Callao, en el Perú, donde varios españoles se habían insurreccionado. Ante esto, se impartieron instrucciones al intendente del departamento del Magdalena para que aquellos prisioneros elevaran juramento de que se comprometieran a no actuar en contra de la República bajo la amenaza de que, en caso de incumplimiento, serían pasados por las armas o confinados a alguna isla española o extranjera (Acuerdos, 1988, t. I, p. 207).

\section{LOS CANJES EN VENEZUELA TRAS LA FIRMA DEL ARMISTICIO DE TRUJILLO}

La mayoría de intenciones de canje en los primeros años de lucha independentista en Venezuela habían resultado también infructuosas y casi siempre con consecuencias fatales para las partes en conflicto.

Un total de 264 patriotas venezolanos capturados por el ejército realista fueron enviados en 1812 a Puerto Rico y de allí a Santa Marta. Al no ser admitidos en esta ciudad por provenir de La Guaira, lugar que había sido escenario de reiteradas convulsiones políticas, el alcalde de primer voto, Rafael Zúñiga, los envió el 24 de julio a Portobelo, donde arribaron al cabo de cinco días a pesar de la queja del gobernador de este puerto panameño de que carecía de recursos suficientes para mantenerlos (AGN, F. Historia, t. 14, ff. 132r-136v).

En agosto de 1813, Simón Bolívar había recuperado el control de Venezuela $y$, por razones humanitarias, propuso al oficial español Domingo Monteverde un canje de prisioneros pero recibió como respuesta un rotundo rechazo. A partir de allí y, en el marco de la guerra a muerte decretada por aquel oficial republicano, comenzó una serie de retaliaciones en donde la práctica común era poner a los prisioneros en la línea de fuego del enemigo. En ese escalamiento de odios, Bolívar mandó luego a sacrificar varios presos españoles en Caracas y La Guaira, procedimiento que de igual modo aplicó a manera de represalia la guarnición española con los patriotas presos (Cochrane, 1994, pp. 127-130). De nada valieron los intentos de mediación del gobernador de Curazao, al recordar Bolívar el 2 de octubre desde su cuartel general de Valencia los excesos cometidos por los españoles, como la ejecución en Barcelona del coronel Antonio Nicolás Briceño y otros 16 oficiales patriotas a manos del capitán español Antonio Tiscar y Pedrosa; iguales ejecuciones arbitrarias se registraron en Calabozo, Espino, Cumaná y otras provincias (Argos de la Nueva Granada, 21 de abril de 1814, pp. 94-95). 
Fue también de gran impacto la ejecución del general Pedro María Freites, quien, con otros compañeros de armas y por orden del comandante español Pablo Morillo, había caído prisionero el 7 de abril de 1817 en la batalla de la Casa Fuerte de Barcelona luego de ser herido tras el ataque de las tropas españolas. Aunque había surgido como última vía salvadora una oferta para intercambiarlos, al final fue despreciada por la alta oficialidad realista (Archivo Santander, Vol. VI, p. 103); (RAH, signatura 9/7663, legajo 20, c), ff. 308r-309v.).

Ante las desconfianzas y sospechas, cada uno de los dos bandos en conflicto no vaciló al momento de estrechar la vigilancia sobre los prisioneros de guerra. En la sesión del 14 de junio de 1819 del Congreso de Angostura, el diputado Domingo Alzuru puso de presente los males que resultaban de conceder pasaportes a los prisioneros españoles enviados a provincias que aún estaban en poder de los realistas. Se propuso que lo mejor era remitirlos a la isla de Margarita para que fueran incorporados en las filas de los corsarios o destinarlos a aquellos parajes en los que se tuviese la certeza de que no causarían perjuicios a la República (Actas, 1988, p. 103).

Tras varios años de cruenta lucha en territorio venezolano, atizada por odios entre grupos étnicos, paulatinamente empezaron a observarse algunos acercamientos entre ambos bandos en el propósito mutuo por recuperar a sus combatientes caídos en prisión. Eso fue lo que se observó a finales de 1820, en medio de los primeros acercamientos de diálogo entre el comandante en jefe español Pablo Morillo y el general Simón Bolívar con miras a firmar un armisticio como ambiente preparatorio para un posterior tratado de paz. De algún modo, esto contribuyó a mantener este tema en el orden de prioridades.

Fue así como el 18 de noviembre, desde su cuartel general de Trujillo, el Libertador agradeció al general Morillo por el "acto de civilidad" que acababa de realizar con la devolución de los prisioneros del regimiento de Dragones. Correspondiendo a este "generoso" gesto, Bolívar se comprometió a enviar al cuartel general español ubicado a pocas leguas de allí, en Carache, igual número de militares que estaban en poder de los republicanos, para lo cual prometió escoger a los “más veteranos y aguerridos" (O 'Leary, 1983, t. XVII, p. 560).

El 23 de noviembre de 1820 Morillo todavía no había recibido el "reemplazo" de otros tres prisioneros que él había remitido y que los dirigentes republicanos habían ofrecido enviar. Así, entonces, le pidió encarecidamente al comisionado de paz, Ramón Correa, que en el próximo encuentro le recordara a la contraparte el cumplimiento de esta promesa ( $\mathrm{O}^{\prime}$ Leary, 1983, t. XI, p. 502). 
Es claro que, bajo el impulso de la tregua y del tratado de regularización suscritos el 25 y 26 de noviembre en Trujillo, se incrementaron las propuestas de intercambio de prisioneros. El 2 de febrero el gobernador republicano de la isla de Margarita, el general Juan Bautista Arismendi, formalizó con el comisionado español José Antonio Pales el canje de seis oficiales españoles que se hallaban prisioneros en esta isla a cambio de igual número de prisioneros republicanos situados en Cumaná. Además, el gobernador español de esta plaza propuso canjear 18 prisioneros republicanos de inferior clase que permanecían allí cautivos a cambio de seis militares españoles recluidos en aquella isla. ${ }^{8}$ Se acordó entonces, según lo estipulado por la Ordenanza, la entrega de cuatro hombres de inferior rango por un capitán, tres por un teniente y dos por un subteniente.

En desarrollo de estos acuerdos, el 6 de febrero se embarcaron en Cumaná con destino a la isla de Margarita 17 prisioneros republicanos, pues uno de ellos, de apellido Iglesias, había escapado del hospital en donde estaba recluido mientras que el gobernador de Cumaná se comprometió a entregar en los próximos días los correspondientes al canje de los cinco prisioneros adicionales. Aclaró el comandante de Margarita que solo le quedaban dos prisioneros que le habían remitido de Carúpano y Cariaco.

Ante la falta de recursos en esta isla y, como un voto de confianza, se aprovechó la ocasión para transportar en la misma embarcación a otros 5 prisioneros con el compromiso de que debían abstenerse de tomar las armas contra la República hasta tanto no se formalizara su canje. Todo esto bajo la condición de que este intercambio se efectuara a la mayor brevedad posible con prisioneros republicanos que estuvieren en Cumaná o Puerto Cabello o en cualquier otro punto ocupado por las tropas españolas.

Con relación a los oficiales españoles Antonio José y Lorenzo Fernández de la Flor y los soldados Macario Martínez y Lorenzo Pérez, consideraba el general Arismendi que no podían incluirse en el intercambio por haber tomado voluntariamente el servicio de las armas republicanas pues los dos primeros habían marchado al Ejército Libertador y los otros se hallaban sirviendo en la isla. Tanto Arismendi como el gobernador español quedaron complacidos con el espíritu de entendimiento que había reinado en este arreglo en reverencia al tratado de regularización de la guerra (AGN, Fondo Secretaría de Guerra y Marina, t. 334, ff. 599r-605v).

${ }^{8}$ Estos oficiales eran los capitanes Manuel López y José Manuel Casares y los subalternos Lamela, Salgado, Calderón y Palenciano. 
Durante estas semanas de tregua se observa, además, el interés de cada bando por el respeto y cuidado de los prisioneros a su cargo. El 25 de febrero de 1821 el general Bolívar comisionó al gobernador político de la provincia de Mérida, coronel Paredes, para que adelantara una investigación contra el comandante interino, el teniente coronel Miguel Segarra, por haber castigado a un prisionero español. Particularmente debía determinarse si este hecho había sucedido después de firmado el tratado de regularización de la guerra. Para desarrollar su labor de investigación debía aquel juez levantar los testimonios necesarios (O 'Leary, 1983, t. XVIII, p. 89).

Estando ya anunciada la suspensión del armisticio, el general Bolívar le reclamó el 28 de marzo al general Miguel de La Torre que ya le había remitido los presos españoles que tenían en Santa Marta y la isla de Margarita pero sin haber recibido aún respuesta alguna. Por ello, se estaba a la espera de que el gobierno español concediera pasaporte al coronel Juan Escalona y a los demás oficiales y tropa que fueran objeto de canje. Sobre el particular, La Torre fue muy enfático en señalar que a Escalona se le había autorizado salida para los colonias caribeñas mientras que los demás prisioneros contaron con la opción de quedarse o de regresar a sus huestes de origen para lo cual el gobierno español había mostrado su indeclinable posición de expedirles los respectivos pasaportes ( $\mathrm{O}^{\prime}$ Leary, t. XVIII, p. 160-167).

En desarrollo de lo dispuesto en el armisticio fue firmado un nuevo acuerdo de canje entre el general republicano Arismendi y el gobernador español de Cumaná, el coronel Antonio Tovar. El 3 de abril el gobierno republicano se enteró de que el capitán Guerrero, del batallón de Angostura, quien había caído prisionero en la campaña de 1818, permanecía todavía confinado en el puerto de La Guaira. El vicepresidente Carlos Soublette encomendó al general Arismendi para que pasase a Caracas con el fin de formalizar el intercambio de dicho capitán por algunos de los cinco subalternos españoles que todavía estaban en poder de los republicanos (AGN, Fondo Secretaría de Guerra y Marina, t. 1.459, f. 432r).

Finalmente, el 28 de abril se rompió la tregua en territorio venezolano y los bandos en conflicto reanudaron sus acciones bélicas con la incertidumbre de no saber si esta novedad perturbaría los avances alcanzados en los acuerdos de canje. El 28 de junio entró en Cumaná la embarcación Hércules, transportando 22 prisioneros de guerra que los españoles habían recuperado luego de haberlos canjeado por igual número de los prisioneros republicanos que se hallaban en Carúpano.

Justo por estos días tendría lugar el suceso más definitivo para Venezuela: la batalla de Carabobo. Aunque después de esta acción militar no se pactó formal- 
mente una capitulación, sí prevaleció la voluntad del bando vencedor de respetar a los prisioneros de guerra. Así lo reconoció sin ambages el derrotado general Miguel de La Torre en carta del 6 de julio al general Bolívar:

Ha llegado a mí noticia que por V. E. han sido tratados con toda consideración los individuos del ejército de mi mando que han tenido la desgracia de ser prisioneros de guerra. Doy a V. E. las debidas gracias por este rasgo de humanidad, que me hace disminuir el sentimiento de suerte de dichos individuos; esperando que continuará V. E. de este modo dando pruebas nada equívocas de que hace renacer las virtudes sociales que habían desaparecido por el enardecimiento de las pasiones que han desolado estos fértiles países (Rojas, 2006, p. 155)9 .

A los cuatro días, desde su cuartel general de Valencia, Bolívar respondió reiterando que ese mismo trato hacia los prisioneros se había puesto en práctica en otras áreas después de decretada la reapertura de hostilidades, expresando de antemano su firme convicción de seguir a futuro en esa misma tónica ( $\mathrm{O}$ 'Leary, 1983, t. XVIII, p. 381).

A mediados de septiembre, Bolívar dio la orden de establecer en el puerto de La Guaira el depósito de prisioneros donde debían remitirse en adelante los que estuviesen en otras provincias. De igual manera, el vicepresidente de Venezuela recibió instrucciones de poner a disposición de su homólogo de Cundinamarca los prisioneros que él requiriera para canjear los que en territorio neogranadino hubiese tomado el enemigo (O 'Leary, 1983, t. 18, p. 515).

Sea cual fuere el destino, definitivamente no fue fácil para los prisioneros manejar esta situación que los privaba de su libertad. No menos complicado pudo resultar este tipo de situaciones para sus familiares. La ciudadana Micaela Valdés, esposa del oficial don José Manuel Casares, uno de los prisioneros de guerra tomados en Cariaco el 25 de noviembre de 1820, se presentó a principios de febrero del año siguiente con sus hijos menores poniendo de presente ante el gobierno republicano su crítica situación económica y reclamando una hacienda de cacao ubicada en Río Caribes que había sido embargada. Su justificación era que había sido plantada y trabajada no solo por él sino con el trabajo de ella. Con base en la ley del 16 de junio de 1819 se decidió entregarle este bien (AGN, Fondo Secretaría de Guerra y Marina, t. 349, f. 164r).

\footnotetext{
${ }^{9}$ El texto de esta carta fue publicado en Gaceta de Caracas, julio 18 de 1821, p. 22, y en Gazeta Ministerial de Chile, febrero 9 de 1822, pp. 146-147.
} 


\section{LOS PRISIONEROS DURANTE LAS CAPITULACIONES DE LAS CIUDADES COSTERAS VENEZOLANAS}

Durante las sucesivas rendiciones de los puertos venezolanos que estaban bajo dominio español se pactaron algunas condiciones para la entrega de los militares de las guarniciones que defendían estas plazas, a quienes se les ofrecieron garantías como prisioneros de guerra.

El coronel español José Pereira había logrado vencer al general Francisco Bermúdez en Caracas pero, tras la derrota sufrida por el grueso del ejército realista el 24 de junio de 1821 en la batalla de Carabobo, quedó aislado y fue perseguido en momentos en que buscaba afanosamente escaparse. Este oficial salió por la costa de Sotavento hasta el pueblo de Carayaca para ver si se encontraba con la escuadra española, pero al perder esta esperanza regresó a La Guaira, donde aún ondeaba la bandera española. Como en este puerto no recibió ningún auxilio de los buques de Puerto Cabello, Pereira no tuvo otra alternativa que rendirse (Páez, t. I, 1973, pp. 209-210).

Al llegar Bolívar a Caracas, propuso el 2 de julio a las autoridades de La Guaira una capitulación en la que se dispuso que Pereira y los demás oficiales de la división, aunque quedaban en condición de prisioneros de guerra, no serían tratados como tales sino que permanecerían en libertad y se les concederían pasaportes para regresar a España bajo la condición de nunca más empuñar las armas contra la República sino cuando se fuesen concretando los canjes correspondientes del gobierno español.

La tropa española quedaría prisionera y con la voluntad autónoma de tomar o no el servicio de las armas republicanas o de radicarse en la provincia que eligieren. Los demás serían licenciados, pudiendo retornar a sus casas. Los oficiales y la tropa conservarían sus bagajes y los jefes podían conservar sus armas. Esta última disposición se hacía extensiva a los vecinos que, en condición de emigrados siguieran la marcha de la división, para lo cual recibirían los respectivos pasaportes.

Las armas, municiones, fornituras y demás objetos militares serían entregados a los mandos republicanos. Como punto final, se dispuso que la división recibiría los honores militares en el acto de rendición de armas. Al edecán del Libertador, teniente coronel Diego Ibarra, se le encargó la misión de concluir este acuerdo de capitulación que debía desarrollarse en un día.

En desarrollo del acuerdo, un total de 200 hombres se embarcaron y el resto se incorporó a las armas republicanas (AHA, F. Gobernación de Antioquia, t. 926, 
f. 70r). No obstante, Pereira incumplió lo convenido, pues a los pocos días se incorporó a las fuerzas de Puerto Cabello que ahora estaban bajo el mando del general La Torre. Esto suscitó una nota de protesta del Libertador Simón Bolívar ante esta clara violación de la capitulación firmada. A través del teniente coronel Churruca le envió a La Torre el listado de oficiales prisioneros que deseaban restituirse a la nación española y se informó que en los hospitales quedaban algunos oficiales que estaban en libertad de restituirse a sus banderas, conforme al tratado de regularización de la guerra ( $\mathrm{O}^{\prime}$ Leary, t. XVIII, p. 382).

En carta enviada desde Valencia el 19 de julio el presidente Simón Bolívar le reclamó al general La Torre por no haber enviado la lista de toda la tropa comprometida en la capitulación sino únicamente la de los oficiales. Reiteró que fue el mismo oficial Pereira quien propuso que ningún militar podía servir contra la República durante el transcurso de la guerra.

Respecto a la tropa realista de origen americano, aclaró Bolívar que nada se había especificado por escrito pero sugería que debían incluirse en la regla general de las capitulaciones, es decir, debían entrar en la categoría de prisioneros hasta que fuesen canjeados. Bolívar consideraba inconveniente la idea de querer sujetar a canje al capitán y a los 42 soldados patriotas que permanecían prisioneros en poder del coronel Pereira al momento de la firma de la capitulación. No consideraba lógico que una división que se rendía pudiera conservar en su poder otros prisioneros siendo que en estos casos los vencedores eran los que debían tener más derechos (O’Leary, t. XVIII, pp. 398-399).

De los 700 negros, mulatos y zambos que componían la infantería, solo seis se inclinaron por tomar las armas republicanas, mientras que mayor fue el número que tomó ese partido entre los cerca de 70 hombres de caballería, en su mayoría europeos (Páez, 1973, t. I, p. 210).

En las capitulaciones firmadas el 15 de octubre de 1821 entre el jefe republicano del Ejército de Oriente, general José Francisco Bermúdez, y el capitán español Juan Bautista de Insusarri para la rendición de la plaza de Cumaná, se acordó que la guarnición sería prisionera de guerra y saldría con los honores correspondientes (Gaceta de Caracas, noviembre 1 de 1821, p. 2; Colección de documentos, Vol. III, pp. 31-38). Fueron en total 700 hombres que empezaron a preparar el viaje.

Finalmente, los prisioneros se embarcaron el 17 de octubre y arribaron el 24 a Puerto Rico. En la acción militar del 16 de junio de 1823, que terminó con la toma de la plaza de Maracaibo, los republicanos capturaron a algunos militares españoles que fueron enviados al general en jefe del Ejército de Venezuela. De esa 
lista hay que mencionar al coronel Jaime Moreno, el teniente coronel Pedro Guerrero, los capitanes Juan Rincón, Felipe Pirela y Felipe Hurtado, los tenientes Cleto Jácome, Ramón Valbuena y Trinidad González, los subtenientes Vicente Mas y Cayetano Melero, y el regidor Juan Ignacio Jácome (AGN, Fondo Secretaría de Guerra y Marina, t. 41, f. 28r).

Días después, el 24 de julio, tuvo lugar un combate naval que estrechó aún más la presión sobre la plaza. Allí se tomaron cerca de 400 prisioneros, de los cuales dos oficiales se pasaron al partido republicano (AGN, Fondo Secretaría de Guerra y Marina, t. 41, f. 105r). Encabezaban la lista el brigadier Sebastián de la Calzada, comandante general de tropas, el teniente coronel Ángel Loño, siete capitanes, siete tenientes, 12 subtenientes, dos cirujanos, cinco practicantes y 213 hombres de tropa. Entre los funcionarios estaba el jefe superior político e intendente don Diego de Alegría y el auditor de guerra don José Manuel Oropesa (AGN, Fondo Secretaría de Guerra y Marina, t. 39, f. 372r).

Las fuerzas patriotas de mar y tierra estrecharon el cerco sobre esta plaza, logrando finalmente su rendición. El 3 de agosto, después de muchas contingencias, fueron firmadas las capitulaciones en las que se estipularon garantías para los prisioneros de guerra con posibilidad de elegir sus destinos, ya fuera sirviendo en las banderas republicanas o continuando al servicio del Rey. Los que optaran por esto último "[...] se tratarán y reputarán como prisioneros de guerra, sin ser molestados, bajo la especial vigilancia de los garantes de que se hablará, hasta tanto que los canjee dicho Gobierno o sus funcionarios, comprendiendo en este artículo a los marineros" (Colección de Documentos, Vol. III, p. 295).

Una vez rendida la ciudad de Maracaibo, quedó Puerto Cabello como el último bastión monárquico en tierras venezolanas. Cuando en el mes de noviembre de 1823 esta plaza fue tomada por las tropas al mando del general José Antonio Páez, el coronel Sebastián de la Calzada era el segundo al mando del último reducto del ejército expedicionario que defendía de esta plaza (Moreno, 1974, t. II, p. 99). Tras haber capitulado el primero al mando de las tropas españolas, general Francisco Tomás Morales, Calzada fue tomado prisionero. Posteriormente fue liberado y enviado a Cuba.

Finalmente, el 10 de noviembre fueron pactados los términos de las capitulaciones. En esta ocasión, se produjo un punto de ruptura con relación al destino de los prisioneros puesto que, a diferencia de los tratados anteriores, en el artículo 4o del convenio se dejó en claro que ningún militar ni empleado de la plaza podía considerarse como prisionero de guerra. Sin embargo, en el numeral 12 los espa- 
ñoles propusieron que el gobierno republicano debía brindar los recursos necesarios para el traslado a posesiones españolas de todos los prisioneros españoles existentes en La Guaira, Cartagena o cualquier otro punto de Cundinamarca y Venezuela. El general patriota José Antonio Páez negó esta petición por considerar que no tenía facultades para decidir sobre este asunto aunque prometió transmitir la inquietud al alto gobierno (Páez, 1973, t. I, pp. 238-239).

Páez se mostró desconcertado por el poco agrado que le había generado al vicepresidente Santander los términos de la capitulación, especialmente por la decisión de dejar en libertad a los prisioneros. Aclaró haberse inclinado por esta medida motivado por circunstancias políticas que rodearon dicha coyuntura: “[...] en aquel momento fui un poco generoso, porque debí serlo; yo podía disponer en aquel momento de las vidas de mis prisioneros, y si les di la libertad fue a consecuencia de mil razones de política que solo estaban al alcance del que las palpaba de cerca" (Cortázar, 1969, Vol. x, p. 140).

Queda como reto historiográfico indagar sobre el destino de aquellos militares españoles que partieron de los territorios liberados. Por lo menos se sabe de la suerte de uno de los que salieron de Puerto Cabello, Manuel Lorenzo, quien permaneció en Cuba hasta mediados de 1824 y regresó a España por el puerto de Santander. Según las instrucciones impartidas en aquella isla, se presentó ante el capitán general de Valladolid, donde le expidieron como a todos los que retornaban del Nuevo Mundo una licencia el 17 de agosto de 1824 con vigencia hasta el 12 de noviembre de 1825. Fue sometido a juicio de calificación, requisito indispensable para agregarlo a algún cuerpo. Sin embargo, buscarle un nuevo destino fue una tarea realmente complicada debido a la gran cantidad de jefes y oficiales que regresaban de América y al tamaño reducido del ejército español que durante esos años estaba en proceso de reestructuración. Al poco tiempo fue llamado a servir en las milicias (Muriel, 2012, p. 335).

\section{A MANERA DE COROLARIO}

Tras vivirse en el territorio de la Nueva Granada y Venezuela una guerra de independencia prolongada y cruenta entre republicanos y españoles, la firma del armisticio y del tratado de regularización de la guerra a finales de noviembre de 1820 abrió nuevos canales de diálogo y concertación, siendo el canje de prisioneros una de las más importantes medidas humanitarias incorporadas en aquel marco regulatorio. 
En últimas, el objetivo con este tipo de prácticas era contener las represalias y los tratos degradantes, así como también procurar la reincorporación social de aquellos combatientes, muchos de los cuales llevaban más de una década ininterrumpida de lucha militar. De algún modo, los acuerdos de intercambio de prisioneros contribuyeron a aliviar la situación de más de 300 combatientes en la fase final de la guerra que había adquirido proporciones mayores en la región de la Costa Caribe neogranadina y venezolana. Otros más resultarían beneficiados por cuenta de los intercambios de prisioneros pactados en la otra zona en disputa ubicada al sur de la Nueva Granada y en Quito, particularmente en las provincias de Popayán, Pasto, Guayaquil y Quito.

Es apenas comprensible el interés de los líderes políticos y militares de ambos bandos por finiquitar los acuerdos de intercambio en una situación en la cual eran críticas las probabilidades de mantener el pie de fuerza, especialmente en el caso de las tropas españolas que mostraban ya un agotamiento y una incertidumbre ante las esperanzas cada vez más lejanas de recibir refuerzos desde España.

Sin duda, el mayor beneficio que se obtuvo a largo plazo con la medida del canje de prisioneros es que pudo sostenerse aún después de la suspensión del periodo de tregua, lo cual significó un pretexto para mantener activos algunos canales de comunicación.

Desde luego, no resulta difícil entender que el intercambio de prisioneros, así como otras medidas humanitarias fijadas en el tratado de regularización, estuvieran exentas de dificultades y tropiezos. La distancia geográfica para el envío de las comunicaciones, la falta de voluntad y disposición en algunos sectores de la oficialidad, los vacíos en la normatividad del tratado, las infracciones al $\operatorname{armisticio}^{10} \mathrm{y}$ los actos graves de hostilidad, fueron factores que generaron demoras y desconfianzas en las decisiones en torno a estos procesos de canje.

Pero, aún con todos los escollos registrados, no hay que olvidar que, gracias al tratado de regularización de la guerra, muchos prisioneros fueron librados de ir al cadalso o de padecer vejámenes y represiones. Eventualmente, los militares en los acuerdos de intercambio pudieron acceder a otra clase de beneficios, como los indultos.

Para los prisioneros incluidos en estos procesos de canje esto implicó algunos compromisos explícitos como el de no empuñar armas en contra del bando que los había liberado, en tanto que al retornar a sus filas de origen pudieron suminis-

\footnotetext{
${ }^{10}$ Entre estos hechos, quizás los que generaron mayor desconfianza fueron los movimientos independentistas ocurridos en Guayaquil y Maracaibo.
} 
trar información valiosa sobre el estado y las operaciones del bando oponente. En particular, para los prisioneros españoles significó una oportunidad para proseguir su vida militar en otros territorios que aún permanecían bajo la égida de España o para regresar a sus casas en la península ibérica después de muchos años de lucha.

Haciendo un balance en términos comparativos, mayores pudieron ser las ventajas para el bando republicano pues un buen número de prisioneros españoles salieron de estos territorios por cuenta de los acuerdos firmados en las capitulaciones, en tanto que una cantidad nada despreciable, en su mayoría de origen americano, optó por quedarse sirviendo a las banderas emancipadoras. Así, entonces, las cifras pudieron redundar en un aumento del pie de fuerza para los republicanos mientras los españoles veían desmoronarse ineluctablemente su ejército expedicionario.

Cabe precisar, por último, que, con estas fórmulas negociadas en torno a los prisioneros de guerra, los españoles terminaron en cierto modo reconociendo la legitimidad del proyecto independentista. Dentro del contexto humanitario y conciliador en que se fraguaron estos acuerdos, las posibilidades de intercambio de prisioneros revelaron, además, el reconocimiento de unos lazos sociales y culturales de vieja data que unían a España con las naciones americanas.

Todas las acciones dirigidas a concretar el intercambio de prisioneros y a buscar las vías humanitarias durante esta fase de Independencia representaron un esfuerzo conjunto de los dirigentes políticos y militares de Nueva Granada y Venezuela, identificados con el propósito unísono de formar una patria libre y soberana, una constatación más del origen común que vinculó a ambos pueblos en sus procesos de formación nacional.

Nuevos retos sobrevendrían después, particularmente con motivo de las guerras civiles que asolaron a Colombia durante sus primeras décadas de vida republicana en donde se recrudecieron los niveles de represión tras la aplicación de la pena capital y la ocurrencia de algunos actos de sevicia aunque, en el marco del derecho de gentes, se optó en algunas ocasiones por el camino del canje como vía de conciliación y tolerancia (Aguilera, 2006, pp. 35-68).

\section{REFERENCIAS}

Academia Colombiana de Historia (ACH), Bogotá-Colombia, Fondo Archivo La Torre. Actas del Congreso de Angostura (1988), Bogotá: Biblioteca de la Presidencia de la República. 
Acuerdos del Consejo de Gobierno de la República de Colombia, 1821-1824 (1988), Bogotá: Biblioteca de la Presidencia de la República, Tomo I.

Aguilera Peña, Mario (2006), "Canje o fusilamiento: los presos políticos en las guerras del siglo XIX”, en: Análisis Político, Vol. 19, No. 58, pp. 35-68.

Alfaro Pareja, Francisco (2013), La Independencia de Venezuela relatada en clave de paz. Las regulaciones pacíficas entre patriotas y realistas (1810-1846), Castellón: Universitat Jaume-I.

Archivo del Libertador. Caracas-Venezuela. Fondo Correspondencia Oficial.

Archivo General de la Nación (AGN), Bogotá-Colombia. Fondos: Enrique Ortega, Historia, Secretaría de Guerra y Marina.

Archivo Histórico Restrepo, Bogotá: Colombia.

Archivo Santander (1916), Bogotá: Águila Negra Editorial, Tomos v-vi.

Argos de la Nueva Granada (1814), Santafé: Imprenta del Congreso de la Nueva Granada.

Biblioteca Nacional de Colombia (BNC), Bogotá-Colombia, Fondo Pineda.

Blanco, José Félix (1875), Documentos para la historia de la vida pública del Libertador, Caracas: Ediciones de la Presidencia de la República, Vol. vII.

Briceño Perozo, Mario (Comp.) (1970), Vida y papeles de Justo Briceño, Caracas: Gráficas Continente.

Cochrane, Charles Stuart (1994), Viajes por Colombia 1823 y 1824, Bogotá: Banco de la República.

Colección de documentos relativos a la vida pública del Libertador (1826), Caracas: Imprenta de Devismes Hermanos, Vol. III.

Corrales, Manuel Ezequiel (1883), Documentos para la historia de la provincia de Cartagena de Indias, Bogotá: Imprenta de Medardo Rivas, Tomo II.

Cortázar, Roberto (Comp.) (1956), Cartas y Mensajes del General Francisco de Paula Santander, Bogotá: Academia Colombiana de Historia, Vol. III.

Cortázar, Roberto (Comp.) (1969), Correspondencia dirigida al General Santander, Bogotá: Academia Colombiana de Historia, Vol. x.

Dousdebés, Pedro Julio (1948), Cartagena de Indias, plaza fuerte, Bogotá: Estado Mayor.

Gaceta de Caracas (1820), Caracas: Imprenta de J. Gutiérrez.

Gazeta de la ciudad de Bogotá, (1821), Bogotá: Imprenta de Nicomedes Lora.

Gazeta de Santa Marta, (1821), Santa Marta: Imprenta del Seminario por Tadeo Rodríguez.

Gazeta Extraordinaria de Bogotá, (1820-1821), Bogotá: Imprenta de Nicomedes Lora. Gazeta Ministerial de Chile, (1822), Santiago: Imprenta del Gobierno. 
Lecuna, Vicente (Comp.) (1942), Cartas de Santander, Caracas: Del Comercio, tomo I.

León Tello, Pilar (1985), El Ejército Expedicionario de Costa Firme: documentos del Conde de Torrepando conservados en el Archivo Histórico Nacional, Madrid: Real Academia de la Historia, Vol. I.

Ley Fundamental de la República de Colombia, (1819), Angostura: [s.n.].

Lynch, John (1983), Las revoluciones hispanoamericanas 1808-1820, Barcelona: Editorial Ariel, 3a edición.

Manifiestos de la correspondencia que ha mediado entre los generales Conde de Cartagena y Don Miguel de La Torre, jefes del Ejército de Costa-Firme con el de los disidentes Don Simón Bolivar, desde el restablecimiento de la Constitución hasta la escandalosa e inesperadas ruptura del armisticio por Bolivar, (1821), Madrid: Imprenta de Espinosa.

Martínez-Radío Garrido, Evaristo (2013), "Los prisioneros en el siglo XVIII y el ejemplo de la Guerra de Sucesión”, Entemu, Vol. xVII, Gijón: UNED, pp. 49-74

Moreno de Ángel, Pilar (1974), Correspondencia y documentos del General José María Córdova, Bogotá: Editorial Kelly, Tomo II.

Muriel Hernández, Manuel (2012), Manuel Lorenzo: militar y gobernador de Santiago de Cuba, Madrid: Tesis Doctoral de la Universidad Complutense de Madrid.

O 'Leary, Simón (1983), Memorias del General O 'Leary, Caracas: Imprenta de la Gaceta Oficial, Tomos XI, XVII, XVIII.

Páez, José Antonio (1973), Autobiografía, Medellín: Editorial Bedout, Tomo I.

Pita Pico, Roger (2017), "Las Capitulaciones en las guerras de Independencia de Colombia: aproximaciones a un estudio comparativo para los casos de Cartagena y Pasto", en: El Taller de la Historia, No. 9, Cartagena, Universidad de Cartagena.

Real Academia de España. Madrid-España. Archivo Histórico Digital.

Rodríguez Villa, Antonio (1908), El teniente general don Pablo Morillo Primer Conde de Cartagena, Marqués de la Fuerte (1778-1837), Madrid: Tipografía de Fortanet, Madrid, Tomo IV.

Rojas, Aristides (2006), Leyendas históricas de Venezuela, Caracas: Editorial CEC.

Salas López, Fernando de (1992), Ordenanzas Militares en España e Hispanoamérica, Madrid: Editorial Mapfre.

Salazar Parada, Gilberto (1990), El pensamiento politico de Santander, Bogotá: Ediciones Norte.

Sourdís Nájera, Adelaida (1994), "Ruptura del estado colonial y tránsito hacia la República 1800-1850”, en Adolfo Meisel Roca, editor, Historia económica y social del Caribe colombiano, Bogotá: Ediciones Uninorte-Ecoe Ediciones. 
Sourdís Nájera, Adelaida (2011), "El consejo de guerra de los mártires de Cartagena en 1816”, en Haroldo Calvo Stevenson y Adolfo Meisel Roca, editores, Cartagena de Indias en la Independencia, Cartagena: Banco de la República.

Thibaud, Clément (2003). República en armas. Los ejércitos bolivarianos en la guerra de Independencia en Colombia y Venezuela. Bogotá: Planeta-Ifea.

Valencia Villa, Alejandro (1992), La humanización de la guerra. Derecho internacional humanitario y conflicto armado en Colombia, Bogotá: Ediciones Uniandes-Tercer Mundo Editores.

Wheaton, Enrique (1861), Historia de los progresos del Derecho de Gentes en Europa y en América, desde la paz de Westfalia hasta nuestros días, Besanzon: Imprenta de José Jacquin. 